Article

\title{
Growth Response of Aspen and Alder to Fresh and Stockpiled Reclamation Soils
}

\author{
Kwadwo Omari ${ }^{1, *}$, Sanatan Das Gupta ${ }^{1}$ and Bradley D. Pinno ${ }^{2(1)}$ \\ 1 Natural Resources Canada, Canadian Forest Service, Edmonton, AB T6H 3S5, Canada; \\ sanatan.dasgupta@canada.ca \\ 2 Department of Renewable Resources, University of Alberta, Edmonton, AB T6G 2E3, Canada; \\ bpinno@ualberta.ca \\ * Correspondence: kwadwo.omari@canada.ca; Tel.: +1-780-430-3849
}

Received: 24 September 2018; Accepted: 15 November 2018; Published: 22 November 2018

\begin{abstract}
Soil stockpiling is a common reclamation practice used in oil sands mining in the boreal forest region of Canada to conserve soil resources; but stockpiling may have detrimental effects on soil quality and plant growth. We examined growth response of trembling aspen (Populus tremuloides Michx.), a fast-growing early successional tree, and green alder (Alnus viridis (Chaix) DC. ssp crispa (Ait.) Turrill), a nitrogen-fixing shrub, to stockpiling and fertilization treatments on two reclamation soils (forest floor mineral mix (FFMM) and peat mineral mix (PMM)). Aspen and alder seeds were planted and their growth monitored for four months in the greenhouse. We found that unfertilized stockpiled FFMM supported significantly higher aspen and alder aboveground biomass than the other fresh and stockpiled soils. Phosphorus and potassium supply rates were highest in stockpiled FFMM and were positively correlated with aboveground plant biomass. There was no significant difference in aspen and alder aboveground biomasses between unfertilized fresh FFMM and PMM soils. Aspen grown in combination with nitrogen-fixing alder did not experience competition or facilitation except on fresh PMM, where aspen height declined. Fertilization increased both aspen and alder growth and eliminated differences in growth between soil types and stockpiling treatments. Our study showed that individual soil properties are more important for revegetation purposes than type of soil or stockpiling treatment.
\end{abstract}

Keywords: fertilization; forest floor mineral mix; green alder; oil sands; peat mineral mix; reclamation; stockpiling; trembling aspen

\section{Introduction}

Open-pit mining in the boreal forest region of Canada involves the removal of vegetation, top soils, and overburden (i.e., material overlaying a deposit of useful geological material) in order to access the underlying bitumen [1]. This practice is followed by land reclamation to restore the disturbed land to a naturally appearing and self-sustaining state that is integrated with the surrounding habitat [2]. When direct placement is not possible, cover soil and other subsoil layers are salvaged and stockpiled for later use in reclamation [3,4]. The physical operations involved in stripping and construction as well as mode and duration of storage may have dramatic effects on the physical, chemical, and biological properties of stockpiled soils [5-7]. Compaction during mound construction and consolidation during storage increases bulk density, damages soil structure, and impedes plant growth [8,9]. Decomposition and development of anaerobic conditions inside the stockpile can significantly reduce seed viability [10] and reduction in viable microorganisms due to stockpiling has also been reported [11].

However, Abdul-Kareem and McRae [3] argue that while adverse effects due to storage can be demonstrated, the extent of deterioration of soil in stockpiles has been greatly overestimated. 
Miller and Cameron [12] reported no change in the diversity of bacteria, fungi, actinomycetes, and algae in 10- and 29-month-old stockpiles compared to nearby undisturbed sites, although species abundance decreased. Dickie et al. [10] also suggested that the seed bank of stockpiled cover soils can be maintained as long as the storage period is no longer than a few months. Although rates of nitrification and counts of aerobic bacteria decreased with storage, there was relatively little soil structure deterioration, and there was a rapid recovery when soil was respread [13]. Thus, the general designation of stockpiled soils being very low in quality could be misleading. Assessing individual soil properties and their relationship to plant growth is needed to determine the usefulness of stockpiled soils for revegetation purposes.

In northern Alberta, reclamation cover soils consist of a mixture of organic matter and the surface mineral soils salvaged prior to mining [14]. The two most common types of cover soils used in this region are forest floor mineral mix (FFMM) salvaged from upland forest sites and peat mineral mix (PMM) salvaged from lowland sites $[14,15]$. Stockpiling FFMM has been shown to adversely affect viability of seeds buried within the stockpile [16]. However, there is little evidence to suggest that reclamation soils stockpiled in cool climates are stagnant in terms of nutrients [17]. In large FFMM stockpiles in the Athabasca Oil Sands Region, Alberta, Canada, total percent organic matter did not change substantially, and available nutrients and soluble ions increased with storage depth and time [16]. However, in smaller FFMM stockpiles, percent organic matter slightly decreased and the increases in available nutrients and soluble cations were not observed [16]. Results from stockpiling peat and peat mineral mixes in Alberta also suggest that stored peat nutrient contents are similar to undisturbed peat, and changes in nutrient or organic carbon levels may be due to admixing with mineral soil [18]. Because the successful re-establishment of vegetation on FFMM and PMM is largely dependent on the nutrients these materials can provide [19], it is important to assess the nutrient status of stockpiled reclamation soils as this would provide a better indication of their suitability for forest-land reclamation than the duration of soil storage.

Fertilization immediately after soil placement is a common practice used in oil sands reclamation in Alberta, and aims to provide an initial pulse of nutrition for planted and naturally regenerated species [20]. The response of plant growth to fertilization in FFMM and PMM is, however, variable. The height of trembling aspen (Populus tremuloides Michx.) was greater in nitrogen-phosphorus-potassium fertilized FFMM and PMM compared to unfertilized treatments [21], but Pinno and Errington [22] found that the average height of aspen and other deciduous tree seedlings did not respond to fertilization in either FFMM or PMM. With the potential loss of nutrients associated with stockpiling [7], it could be expected that fertilizing stockpiled soils to ameliorate nutrient deficiencies could lead to these soils supporting similar plant growth to fresh soils. In addition to fertilization, nitrogen-fixing species may be used to improve the quality of reclamation soils. Native leguminous species were reported to show greater improvement in soil fertility parameters than native non-leguminous species in the restoration of a coal-mined area [23]. The production of readily decomposable nutrient-rich litter and turnover of fine roots and nodules by nitrogen-fixing species allow for substantial nutrient transfer to companion species and subsequent cycling [24-26]. Alder (Alnus viridis (Chaix) DC. ssp crispa (Ait.) Turrill), a nitrogen-fixing shrub, is a native early successional species in the boreal region of Canada and planting it together with other early successional tree species, such as aspen, on oil sands reclamation sites may help improve reclamation soils to meet plant growth requirements.

Establishing aspen and other early successional tree species in oil sands reclamation sites is crucial for soil development because of its rapid growth and contribution to above- and belowground organic matter accumulation, which would increase nutrient availability and improve soil structure [4]. The presence of aspen also assists conifer regeneration and establishment of other forest understory species by reducing exposure and grass competition, and improving soil drainage, water storage, and nutrient availability [4]. In this study, we examined the effect of fresh and stockpiled FFMM and PMM on the growth of early successional species, aspen and nitrogen-fixing alder. Our objectives were to: 
(i) determine the effects of reclamation soil type and stockpiling on aboveground biomass and height of aspen and alder, (ii) determine whether fertilization alters differences in aspen and alder growth among fresh and stockpiled reclamation soils, and (iii) determine if aspen grown in combination with alder experiences competition or facilitation on fresh and stockpiled reclamation soils.

\section{Materials and Methods}

Our experimental set up in the greenhouse consisted of 3 species groups (aspen, alder, and aspen + alder $) \times 2$ soil types $($ FFMM and PMM) $\times 2$ stockpiling treatments (stockpiled and not stockpiled) $\times 2$ fertilization treatments (fertilized and not fertilized) $\times 11-12$ replicates for a total of 281 pots. Additionally, we set up control pots consisting of 7-8 replicates each of four soil types and stockpiling treatments for a total of 31 control pots, which contained no plants and were not fertilized.

The aspen and alder seeds were acquired from the National Tree Seed Centre, located in Fredericton, NB, Canada; they were planted in April 2017 in styroblocks, with a plug size of $2.5 \mathrm{~cm}$ in diameter and $11.3 \mathrm{~cm}$ in length, using commercial garden soil. Soils were watered after sowing and grit was placed on the soil surface to prevent moisture loss. To prevent further moisture loss, the styroblocks were completely covered with clear plastic sheets until seed germination. Seedlings were transplanted into pots (top diameter $=17 \mathrm{~cm}$, bottom diameter $=12 \mathrm{~cm}$, height $=18.5 \mathrm{~cm}$ ) in late June 2017. Seedlings were transplanted with the plug of commercial soil. This was due to the roots of seedlings being severely entangled around the soil plugs, and separating the roots from the commercial soil would have severely damaged the roots. Because all the seedlings were transplanted in the same way, we believe that any error resulting from this is similar for all treatments. Individual aspen and alder seedlings were transplanted into separate pots, hereafter referred to as pure aspen and pure alder, respectively. Pure aspen and alder pots were planted at a density of one seedling per pot. Combinations of aspen and alder seedlings, one of each species, were also transplanted into single pots. Aspen seedlings grown in combination with alder in the same pot are hereafter referred to as mixed aspen.

Standard conditions in the greenhouse were $60 \%$ relative humidity, automated 1-h daily watering approximately equivalent to $13-18 \mathrm{~mm}$ of precipitation, and artificial light when natural light intensity in the greenhouse fell below $200 \mathrm{~W} \mathrm{~m}^{-2}$. The temperature in the greenhouse ranged from $18-20^{\circ} \mathrm{C}$ at night (01:00-06:00) to $22-24{ }^{\circ} \mathrm{C}$ during the day (10:00-20:00), ramping evenly between day and night temperatures.

The two soils used were forest floor mineral mix (FFMM) and peat mineral mix (PMM), and were obtained from an operational mine site in the oil sands region, northern Alberta. The FFMM is salvaged from upland forest soil and consists of the surface organic layers mixed with the underlying mineral soil (A horizons) to a maximum total depth of $30 \mathrm{~cm}$ [27]. The PMM is salvaged from lowland organic soils and consists of a mixture of peat and the underlying mineral soil, at a 60:40 ratio of peat:mineral material [27]. PMM has a greater portion of organic peat, and has a lower bulk density and higher water holding capacity compared to FFMM [22,27]. Each of the FFMM and PMM soils consisted of two stockpiling treatments, which were fresh (freshly salvaged) and stockpiled (1 year and 5 years old storage period for PMM and FFMM, respectively). At the mine site, reclamation soils of varying ages are used in reclamation. The soil types used in this study thus reflected what is operationally available for reclamation efforts. The fresh and stockpiled soils were obtained from different sites but within the same general area. For this study, the stockpiled soils were salvaged by an excavator from the surface of the soil mound to a depth of about $1 \mathrm{~m}$.

Half of the pots were fertilized at a cumulative rate equivalent to $120 \mathrm{~kg} \mathrm{~N} \mathrm{ha}^{-1}$ with a $20-20-20$ nitrogen, phosphorus, and potassium fertilizer to determine the effects of fertilization on growth of aspen and alder grown in fresh and stockpiled reclamation soils. Fertilizer was applied biweekly for the duration of the experiment, except for the last four weeks of the experiment where a double dose of the biweekly amount was applied once. 
Aspen and alder heights were measured each month after transplanting for 3 months, and at the end of the study all the plants were destructively sampled and oven-dried at $50{ }^{\circ} \mathrm{C}$ for at least three weeks to determine the aboveground biomasses.

To estimate soil nutrient supply rates, a pair each of anion and cation plant root simulator (PRS; Western Ag Innovations, Saskatoon, SK, Canada) probes were installed to a depth of $12 \mathrm{~cm}$ in the control pots. PRS probes attract and adsorb ions through electrostatic attraction on an ion-exchange membrane to provide an estimate of soil nutrient supply rates $[27,28]$. The probes were removed after five weeks, washed with deionized water and sent to Western Ag Innovations for extraction and laboratory analysis. $\mathrm{NO}_{3}{ }^{-}$and $\mathrm{NH}_{4}{ }^{+}$supply rates were determined colorimetrically with an automated flow injection analysis system. Supply rates of all other nutrients (phosphorus, potassium, sulphur, iron, and manganese) were determined using inductively coupled plasma spectroscopy.

Aboveground biomass of pure aspen, pure alder, and mixed aspen were separately compared among soil and stockpiling treatments using a two-way factorial analysis of variance (ANOVA). Box-Cox transformation were applied when appropriate to ensure that ANOVA assumptions of normality and/or homoscedasticity were met. Pairwise comparisons (Tukey's test) were used to determine the effect of soil and stockpiling on aboveground biomass.

To determine whether aspen planted in combination with nitrogen-fixing alder in the same pot had a facilitative or competitive interaction, relative height of aspen was calculated as height of aspen grown in combination with alder (mixed aspen height) divided by mean height of aspen grown individually (pure aspen height). A value of $1,>1$, and $<1$ represent no effect, facilitative effect, and competitive effect, respectively. One-tailed, one-sample $t$-test was used to determine if the relative height of aspen was significantly greater or less than 1 . For each species group, correlation analyses were performed between nutrient supply rates from the control pots and aboveground biomass from the unfertilized pots. All statistical comparisons were performed with R statistical software [29].

\section{Results}

The effect of stockpiling on aboveground biomass was dependent on the soil type and species. Aboveground biomass of unfertilized pure aspen and mixed aspen was significantly greater for the stockpiled soils than the fresh soils for both FFMM and PMM (Figure 1a,c). For unfertilized pure alder, stockpiled FFMM supported a higher aboveground biomass than fresh FFMM $(p<0.001)$, but aboveground biomass on fresh PMM was greater than stockpiled PMM $(p=0.064)$ (Figure 1b). For all species groups, there was no significant difference in aboveground biomass between fresh FFMM and fresh PMM, but for the stockpiled soils, FFMM supported a higher aboveground biomass than PMM for pure aspen $(p<0.001)$, mixed aspen $(p=0.002)$, and pure alder $(p<0.001)$ (Figure $1 \mathrm{a}, \mathrm{b})$.

In relation to supply rates of soil nutrients (Table 1), aboveground biomass of unfertilized pure aspen, across the soil and stockpiling treatments, was positively correlated with the supply rate of phosphorus $(r=0.972, p=0.028)$, potassium $(r=0.932, p=0.067)$, and manganese $(r=0.928, p=0.072)$. Aboveground biomass of unfertilized mixed aspen and pure alder was positively correlated with rate of supply of phosphorus $(r=0.915, p=0.085)$ and potassium $(r=0.930, p=0.070)$, respectively. Growth patterns of unfertilized aspen were generally similar among all the soil and stockpiling treatments except for stockpiled FFMM (pure aspen) and fresh PMM (mixed aspen) (Figure 2a,c). For unfertilized pure alder, the growth patterns were generally similar across all the soil and stockpiling treatments (Figure 2b). 


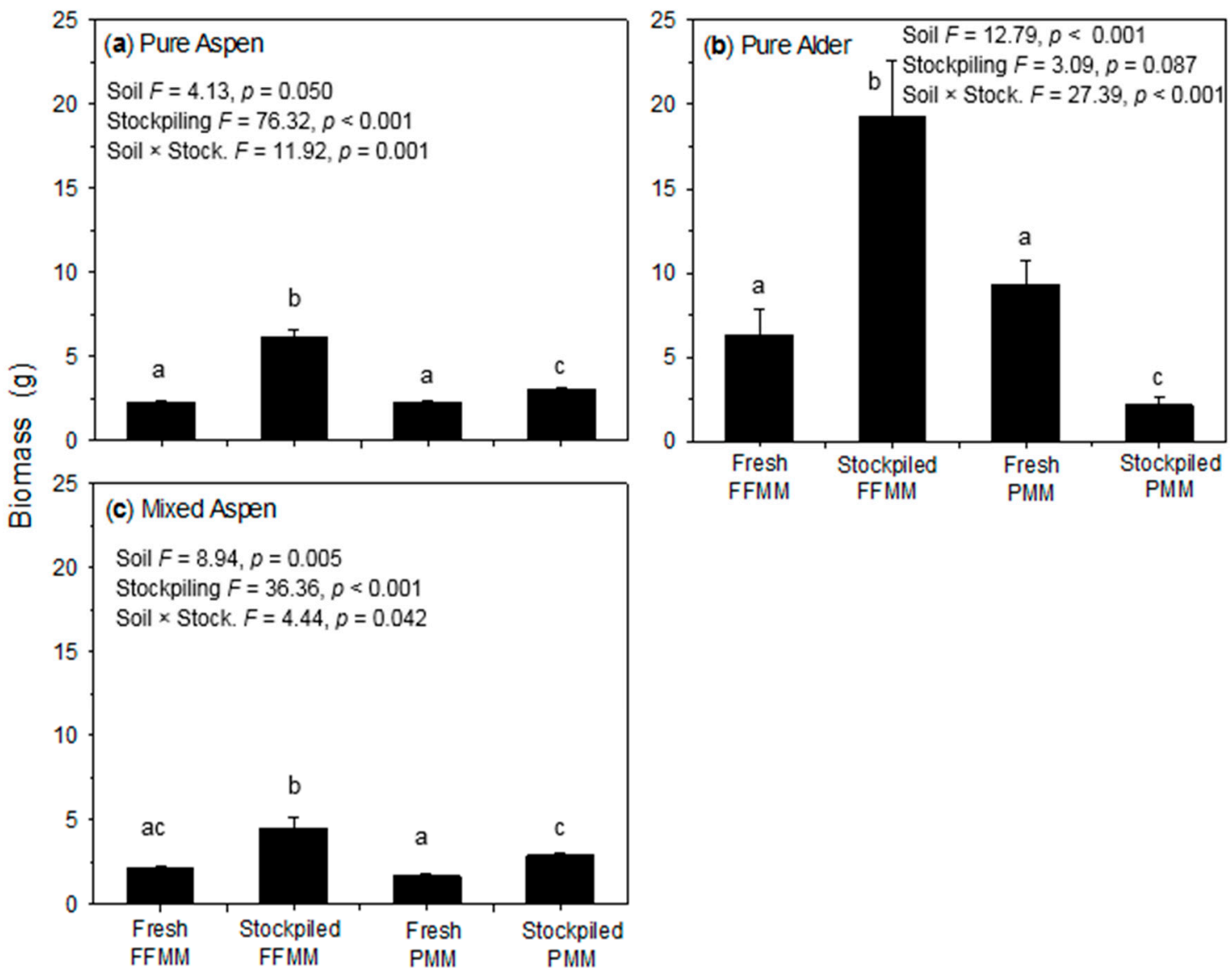

Treatment

Figure 1. Biomass at harvest at age 4 months of aspen and alder planted in unfertilized fresh and stockpiled forest floor mineral mix (FFMM) and peat mineral mix (PMM) soils. Pure aspen (a) and pure alder (b) represent individual aspen and alder, respectively, planted separately. Mixed aspen (c) represents aspen planted in combination with alder. For each species group, treatments that do not share the same letter are significantly different. Error bars are standard errors.

Table 1. Mean values (associated standard errors) of supply rates of soil nutrients over a 5-week period for fresh and stockpiled forest floor mineral mix (FFMM) and peat mineral mix (PMM) soils. Abbreviations: $\mathrm{TIN}=$ total inorganic nitrogen, $\mathrm{P}=$ phosphorus, $\mathrm{K}=$ potassium, $\mathrm{S}=$ Sulphur, $\mathrm{Fe}=$ Iron, and $\mathrm{Mn}=$ Manganese.

\begin{tabular}{|c|c|c|c|c|c|c|c|}
\hline \multirow[b]{2}{*}{ Soil } & \multirow[b]{2}{*}{ Stockpiling } & \multicolumn{6}{|c|}{ Nutrient Availability $\left(\mu \mathrm{g} 10 \mathrm{~cm}^{-2}\right)$} \\
\hline & & TIN & $\mathbf{P}$ & $\mathbf{K}$ & $\mathbf{S}$ & $\mathrm{Fe}$ & Mn \\
\hline FFMM & Fresh & $\begin{array}{l}12.99 \\
(2.35)\end{array}$ & $\begin{array}{c}0.67 \\
(0.16)\end{array}$ & $\begin{array}{c}8.24 \\
(0.64)\end{array}$ & $\begin{array}{c}1243.39 \\
(52.13)\end{array}$ & $\begin{array}{c}95.80 \\
(19.62)\end{array}$ & $\begin{array}{c}9.16 \\
(2.43)\end{array}$ \\
\hline FFMM & Stockpiled & $\begin{array}{l}48.59 \\
(9.60)\end{array}$ & $\begin{array}{c}7.98 \\
(2.60)\end{array}$ & $\begin{array}{l}33.97 \\
(1.72)\end{array}$ & $\begin{array}{l}736.81 \\
(94.85)\end{array}$ & $\begin{array}{l}268.49 \\
(36.02)\end{array}$ & $\begin{array}{c}39.25 \\
(14.01)\end{array}$ \\
\hline PMM & Fresh & $\begin{array}{l}84.56 \\
(18.50)\end{array}$ & $\begin{array}{c}0.39 \\
(0.11)\end{array}$ & $\begin{array}{c}7.13 \\
(0.60)\end{array}$ & $\begin{array}{c}1014.49 \\
(37.01)\end{array}$ & $\begin{array}{l}231.47 \\
(20.12)\end{array}$ & $\begin{array}{c}1.75 \\
(0.60)\end{array}$ \\
\hline PMM & Stockpiled & $\begin{array}{l}39.19 \\
(6.67)\end{array}$ & $\begin{array}{c}0.34 \\
(0.05)\end{array}$ & $\begin{array}{c}2.93 \\
(0.36)\end{array}$ & $\begin{array}{l}969.91 \\
(21.45)\end{array}$ & $\begin{array}{l}144.08 \\
(15.43)\end{array}$ & $\begin{array}{c}0.37 \\
(0.04)\end{array}$ \\
\hline
\end{tabular}




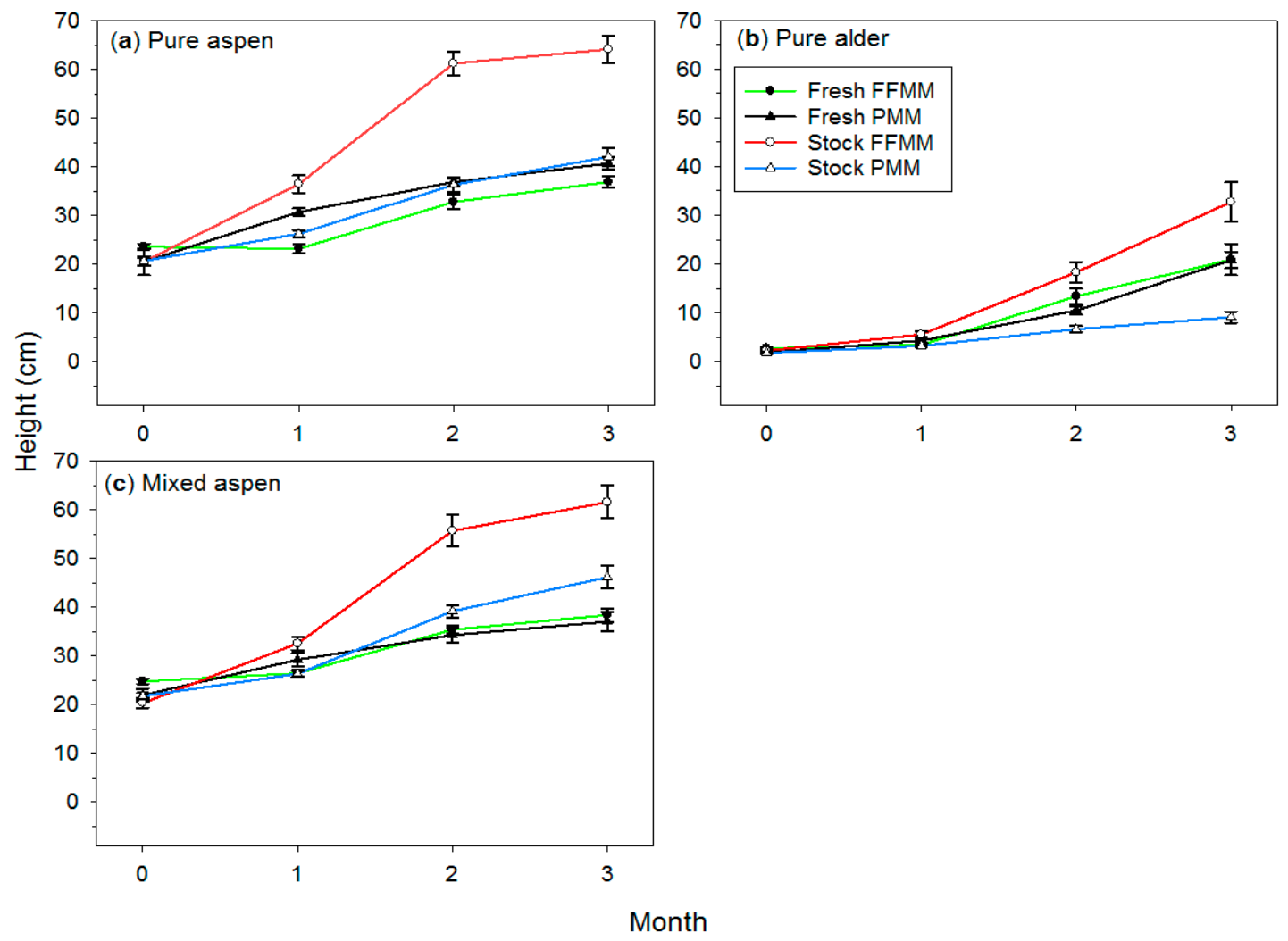

Figure 2. Height of aspen and alder planted in unfertilized fresh and stockpiled forest floor mineral mix (FFMM) and peat mineral mix (PMM) soils. Pure aspen (a) and pure alder (b) represent individual aspen and alder, respectively, planted separately. Mixed aspen (c) represents aspen planted in combination with alder. Height at month zero represents height at transplant, and height at month greater than zero represents post-transplanting height. Error bars are standard errors.

Relative height of unfertilized aspen was not significantly different from 1 for all the soil and stockpiling treatments except for fresh PMM, where aspen relative height was significantly less than 1 ( $p=0.047)$. These indicate that aspen grown in combination with nitrogen-fixing alder did not experience competition or facilitation except on fresh PMM where aspen height declined, indicating competition.

Fertilization increased plant growth and eliminated the differences in aboveground biomass (Figure 3) and growth patterns (Figure 4) among the soil and stockpiling treatments such that there were no differences in biomass among treatments with fertilization for each of the species groups. Relative height of fertilized aspen was also not significantly different from 1 across the soil and stockpiling treatments. 


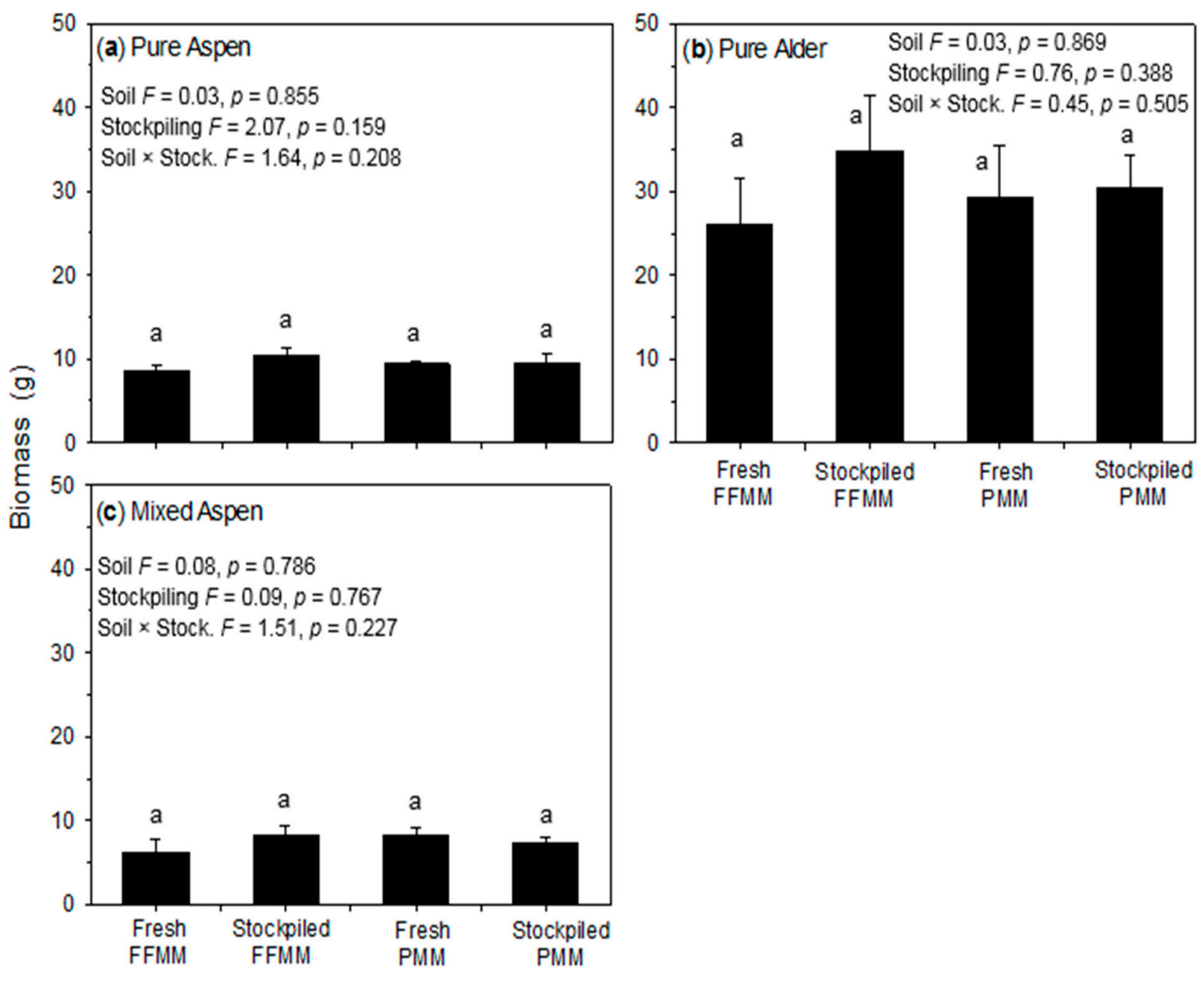

Treatment

Figure 3. Biomass at harvest at age 4 months of aspen and alder planted in fertilized fresh and stockpiled forest floor mineral mix (FFMM) and peat mineral mix (PMM) soils. Pure aspen (a) and pure alder (b) represent individual aspen and alder, respectively, planted separately. Mixed aspen (c) represents aspen planted in combination with alder. For each species group, treatments that share the same letter are not significantly different. Error bars are standard errors. 

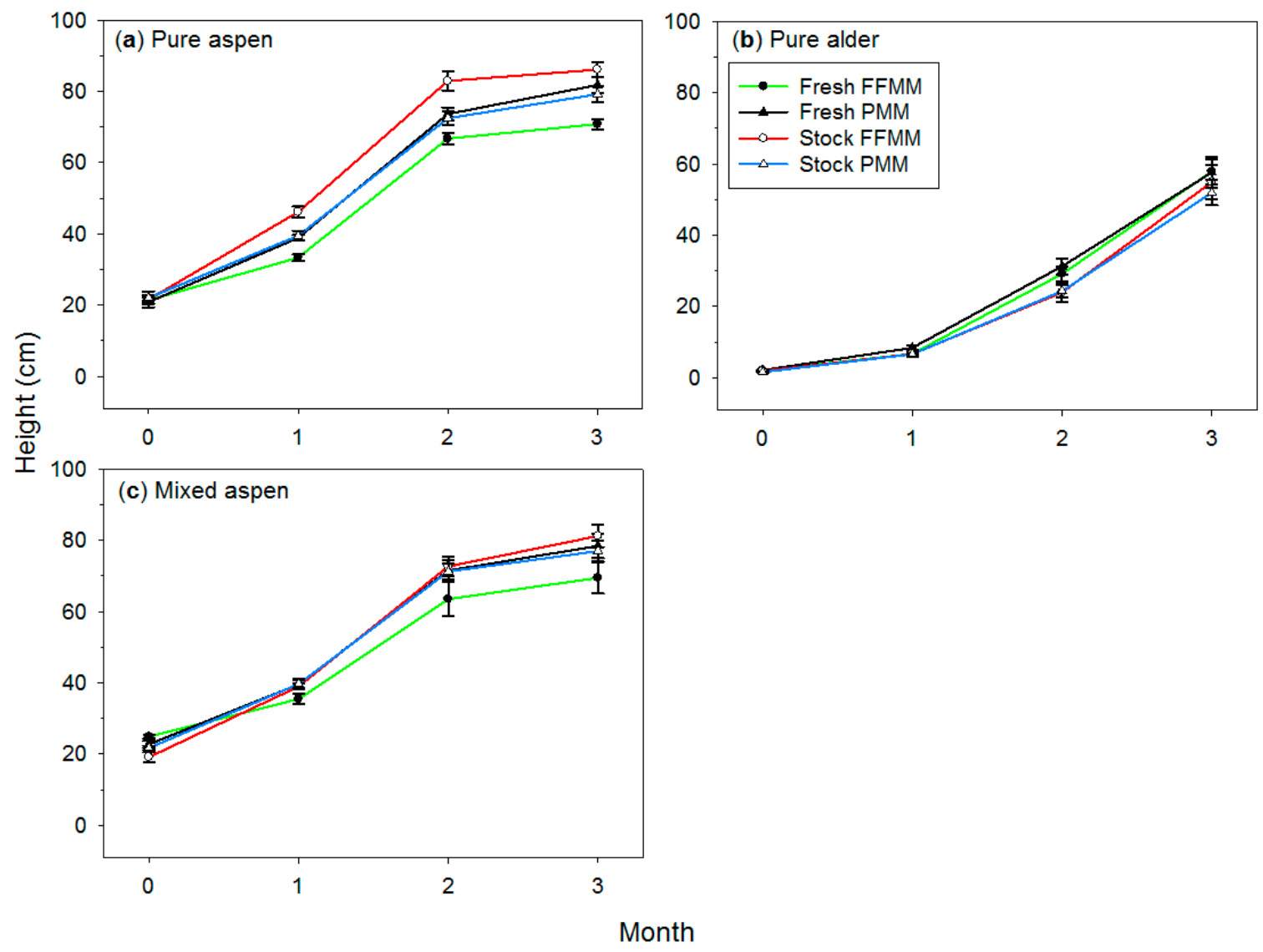

Figure 4. Height of aspen and alder planted in fertilized fresh and stockpiled forest floor mineral mix (FFMM) and peat mineral mix (PMM) soils. Pure aspen (a) and pure alder (b) represent individual aspen and alder, respectively, planted separately. Mixed aspen (c) represents aspen planted in combination with alder. Height at month zero represents height at transplant, and height at month greater than zero represents post-transplanting height. Error bars are standard errors.

\section{Discussion}

Stockpiled soils are generally characterized as being poor in physical, chemical, and biological quality compared to fresh soils $[7,8,11]$ and therefore could be expected to poorly support plant growth. However, we found that stockpiled FFMM supported the best aspen and alder growth of all soil and stockpiling treatments. This is similar to findings by Visser et al. [5], who reported that the primary production potential of stored soil was not adversely affected, but rather shoot production was stimulated after stockpiling. Additionally, we found that between the unfertilized fresh soils there was no significant difference in aspen or alder aboveground biomass between FFMM and PMM. Other studies, however, found that unfertilized PMM better supported aspen growth than FFMM [14,21]. Our findings indicate that individual soil properties are more important for revegetation than stockpiling treatment, and also support the conclusion by Howell et al. [20] that characterization of reclamation soils, which includes physical and chemical characteristics, would be more appropriate than generally classifying them such as FFMM or PMM, stockpiled or fresh.

Across the soil and stockpiling treatments, plant growth was positively correlated with phosphorus (pure and mixed aspen) and potassium (pure aspen and alder) supply rate, with the supply rate of phosphorus and potassium being 12-24 times, and 5-12 times, respectively higher for stockpiled FFMM than the other treatments. MacKenzie [16] found that stockpiling FFMM increased available phosphorus and potassium and did not substantially change total percent nitrogen or organic matter. In our study, the greater amount of phosphorus and potassium in stockpiled FFMM may partly be because the soil was obtained from a potentially more nutrient-rich site than the other soils, 
potential nutrient flush from decomposing or decomposed forest floor material [19], and the likelihood of these nutrients to increase after stockpiling FFMM [16]. The greater amount of phosphorus and potassium in stockpiled FFMM compared to the other soil and stockpiling treatments contributed to the greater plant biomass on the stockpiled soil. This is consistent with a study by Chapin et al. [30], who found that total biomass of aspen seedlings increased with increasing phosphorus supply rate. Applying phosphorus fertilizer to aspen increased height and stem volume [31], and aspen growth has been reported to be positively related to soil extractable potassium [21]. In another study, which analyzed the chemical composition of clayey, sandy, and loamy stockpiles, levels of extractable phosphorus and potassium were comparable to levels acceptable for agricultural purposes, and no adverse effect of stockpiling on chemical fertility was observed except in the case of nitrogen [3]. Ghose [7], however, reported a decrease of 32\%-48\% nitrogen, $23 \%-35 \%$ phosphorus and $28 \%-46 \%$ potassium in soil dumps that had been stockpiled for 1 to 10 years. While adverse effects of stockpiling exist, it appears that the extent of damage depends on the methods of stripping and stockpiling the soil, management of the topsoil, and length of storage time [5,32,33]. In the oil sands region, soils may be stockpiled for several years to decades. Employing better storage and handling techniques could help reduce soil damage and preserve stockpiled soils to meet plant growth requirements. Such techniques include using appropriate machinery to minimize soil compaction, minimizing mixing of top soil with subsoil, reducing depth of stockpiles, ensuring stockpiled soils are not stored beyond their shelf-life (determined from pilot studies), and using nutrient and soil amendments [3,6,7,34,35].

Fertilization substantially increased both aspen and alder growth and eliminated the differences in growth and growth patterns between soil types and stockpiling treatments. This is similar to results by Pinno et al. [21], who found that soil type became less important for plant growth after fertilization with nitrogen, phosphorus, and potassium. Thus, from a nutrient perspective, the type of reclamation soil or period of soil storage is of less importance for revegetation when fertilization is applied. Schott et al. [14], however, reported that growth of aspen on fertilized PMM substantially increased compared to fertilized FFMM; they noted this could be partially due to greater cover by competing vegetation on FFMM. Cultural practices such as weed control may need to be combined with fertilization, especially on fresh or stockpiled FFMM, to enhance tree seedling growth.

Aspen grown in combination with nitrogen-fixing alder did not experience competition or facilitation except in fresh PMM, where aspen growth slightly declined. The decline in mixed aspen growth in fresh PMM is likely due to the very high amount of nitrogen in fresh PMM, along with lower levels of the other macronutrients, so that the nitrogen fixation by alder was redundant for fresh PMM. Positive growth response to increased nitrogen was observed for aspen with greater access to phosphorus [21]. However, with the addition of nitrogen, phosphorus and potassium fertilizer, we found that aspen grown together with alder only grew as much as the fertilized pure aspen for all the soil and stockpiling treatments. In the current study, our observation of an absence of competition or lack of strong competitive effects between aspen and alder suggests that planting them together as early successional species, in fresh or stockpiled reclamation soils is appropriate. Both species would contribute to revegetation efforts and soil development [4,24], without limiting the development of either species.

\section{Conclusions}

We studied the effects of reclamation soil type and stockpiling on the growth of aspen and alder. Findings from our study showed that it was important to assess the individual properties of reclamation soils to determine their suitability for revegetation plans rather than basing decisions on the general soil type or duration of soil storage. Our study was based on short-term growth of aspen and alder with well-regulated environmental conditions in the greenhouse. We therefore recommend long-term field study to help ascertain how fresh and stockpiled reclamation soils from different sites and of varying ages support the development and establishment of plants on reclamation sites under 
conditions of water limitation, competition, and drastic changes in soil temperature. A long-term study will also help ascertain whether alder has a facilitative interaction when planted together with aspen.

Author Contributions: Conceptualization, B.D.P. and S.D.G.; Formal analysis, K.O.; Funding acquisition, B.D.P.; Investigation, K.O. and S.D.G.; Methodology, K.O., S.D.G. and B.D.P.; Supervision, B.D.P.; Writing-Original Draft, K.O.; Writing-Review \& Editing, K.O., S.D.G. and B.D.P.

Funding: This study was funded by Canadian Natural Resources Limited and the Energy Innovation Program of Natural Resources Canada.

Acknowledgments: Aspen and alder seeds used in the study were obtained from the National Tree Seed Centre, Fredericton, NB, Canada. We thank Edith Li for greenhouse assistance.

Conflicts of Interest: The authors declare no conflict of interest.

\section{References}

1. Audet, P.; Pinno, B.D.; Thiffault, E. Reclamation of boreal forest after oil sands mining: Anticipating novel challenges in novel environments. Can. J. For. Res. 2014, 45, 364-371. [CrossRef]

2. Government of Alberta. Environmental Protection and Enhancement Act, Conservation and Reclamation Regulation; Alberta Regulation 115/93; Alberta Queen's Printer: Edmonton, AB, Canada, 1993.

3. Abdul-Kareem, A.W.; McRae, S.G. The effects of topsoil of long-term storage in stockpiles. Plant Soil 1984, 76, 357-363. [CrossRef]

4. Dhar, A.; Comeau, P.G.; Karst, J.; Pinno, B.D.; Chang, S.X.; Naeth, A.M.; Vassov, R.; Bampfylde, C. Plant community development following reclamation of oil sands mine sites in the boreal forest: A review. Environ. Rev. 2018, 26, 286-298. [CrossRef]

5. Visser, S.; Fujikawa, J.; Griffiths, C.L.; Parkinson, D. Effect of topsoil storage on microbial activity, primary production, and decomposition potential. Plant Soil 1984, 82, 41-50. [CrossRef]

6. Johnson, D.B.; Williamson, J.C.; Bailey, A.J. Microbiology of soils at opencast coal sites. I. Short- and long-term transformations in stockpiled soils. J. Soil Sci. 1991, 42, 1-8. [CrossRef]

7. Ghose, M.K. Management of topsoil for geo-environmental reclamation of coal mining areas. Environ. Geol. 2001, 40, 1405-1410.

8. Hunter, F.; Currie, J.A. Structural changes during bulk soil storage. J. Soil Sci. 1956, 7, 75-79. [CrossRef]

9. Sheoran, V.; Sheoar, A.S.; Poonia, P. Soil reclamation of abandoned mine land by revegetation: A review. Int. J. Soil Sediment Water 2010, 3, 1-20.

10. Dickie, J.B.; Gajjar, K.H.; Birch, P.; Harris, J.A. The survival of viable seeds in stored topsoil from opencast coal workings and its implications for site restoration. Biol. Conserv. 1988, 43, 257-265. [CrossRef]

11. Williamson, J.C.; Johnson, B.D. Determination of the activity of soil microbial populations in stored and restored soils at opencast coal sites. Soil Biol. Biochem. 1990, 22, 671-675. [CrossRef]

12. Miller, R.M.; Cameron, R.E. Some Effects of Soil Microbiota on Topsoil Storage during Surface Mining. In Proceedings of the Fourth Symposium on Surface Mining and Reclamation, St. Louis, MO, USA, 19-21 October 1976; National Coal Association: Washington, DC, USA, 1976; pp. 131-139.

13. O'Flanagan, N.C.; Walker, G.J.; Waller, W.M.; Murdoch, G. Changes taking in place in topsoil stored in heaps on opencast sties. NAAS Quart. Rev. 1963, 62, 85-92.

14. Schott, K.M.; Snively, A.E.K.; Landhausser, S.M.; Pinno, B.D. Nutrient loaded seedlings reduce the need for field fertilization and vegetation management on boreal forest reclamation sites. New For. 2016, 47, 393-410. [CrossRef]

15. Naeth, M.A.; Wilkinson, S.R.; Mackenzie, D.D.; Archibald, H.A.; Powter, C.B. Potential of LFH Mineral Soil Mixes for Reclamation of Forested Lands in Alberta; University of Alberta: Edmonton, AB, Canada, 2013.

16. MacKenzie, D.D. Oil Sands Mine Reclamation using Boreal Forest Surface Soil Surface (LFH) in Northern Alberta. Ph.D. Thesis, University of Alberta, Edmonton, AB, Canada, 2012.

17. Alberta Environment and Water. Best management practices for conservation of reclamation materials in the mineable Oil Sands Region of Alberta. Prepared by D. MacKenzie for the Terrestrial Subgroup, Best Management Practices Task Group, Reclamation Working Group of the Cumulative Environmental Management Association, Fort McMurray, AB, Canada, 2012. 
18. Kong, K.; Lindsay, J.D.; McGill, W.B. Characterization of Stored Peat in the Alberta Oil Sands Area; Report for Alberta Environment, Alberta Oil Sands Environmental Research Program: Edmonton, AB, Canada, 1980.

19. Quideau, S.A.; Norris, C.E.; Rees, F.; Dyck, M.; Samadi, N.; Oh, S.-W. Carbon, nitrogen, and phosphorus release from peat and forest floor-based cover soils used during oil sands reclamation. Can. J. Soil Sci. 2017, 97, 757-768. [CrossRef]

20. Howell, D.M.; Das Gupta, S.; Pinno, B.D.; MacKenzie, M.D. Reclaimed soils, fertilizer, and bioavailable nutrients: Determining similarity with natural benchmarks over time. Can. J. Soil Sci. 2017, 97, 149-158. [CrossRef]

21. Pinno, B.D.; Landhausser, S.M.; MacKenzie, M.D.; Quideau, S.A.; Chow, P.S. Trembling aspen seedling establishment, growth and response to fertilization on contrasting soils used in oil sands. Can. J. Soil Sci. 2012, 92, 143-151. [CrossRef]

22. Pinno, B.D.; Errington, R.C. Maximizing natural trembling aspen seedling establishment on a reclaimed boreal oil sands site. Ecol. Restor. 2015, 33, 43-50. [CrossRef]

23. Singh, J.S.; Singh, K.P.; Jha, A.K. Final Technical Report Submitted to the Ministry of Coal; Government of India: New Delhi, India, 1996; p. 116.

24. Jefferies, R.A.; Willson, K.; Bradshaw, A.D. The potential of legumes as a nitrogen source for the reclamation of direct land. Plant Soil 1981, 59, 173-177. [CrossRef]

25. Bernhard-Reversat, F. Soil nitrogen mineralization under a Eucalyptus plantation and a natural Acacia forest in Senegal. For. Ecol. Manag. 1988, 23, 233-244. [CrossRef]

26. Montagnini, F.; Sancho, F. Impacts of native trees on tropical soils: A study in the Atlantic lowlands of Costa Rica. Ambio 1990, 19, 386-390.

27. Errington, R.C.; Pinno, B. Early successional plant community dynamics on a reclaimed oil sands mine in comparison with natural boreal forest communities. Écoscience 2016, 22, 133-144. [CrossRef]

28. Davies, K.W.; Nafus, A.M.; Sheley, R.L. Non-native competitive perennial grass impedes the spread of an invasive annual grass. Biol. Invasions 2010, 12, 3187-3194. [CrossRef]

29. R Core Team. The R Foundation for Statistical Computing, Version 3.5.0. 2018.

30. Chapin, F.S., III; Tryon, P.R.; Van Cleve, K. Influence of phosphorus on growth and biomass distribution of Alaskan taiga tree seedlings. Can. J. For. Res. 1983, 13, 1092-1098. [CrossRef]

31. Van den Driessche, R.; Niemi, F.; Charleson, L. Fourth year response of aspen seedlings to lime, nitrogen and phosphorus applied at planting and 1 year after planting. For. Ecol. Manag. 2005, 219, 216-228. [CrossRef]

32. Miller, M.R.; May, S.W. Below-Ground Ecosystems Project. In Land Reclamation Program Annual Report; Argonne Natl. Lab.: Argonne, IL, USA, 1979; pp. 64-70.

33. Ross, D.J.; Cairns, A. Nitrogen availability and microbial biomass in stockpiled topsoils in Southland. N. Z. J. Sci. 1981, 24, 137-143.

34. Sendlein, V.A.; Lyle, Y.H.; Carlson, L.C. Surface Mining Environmental Monitoring and Reclamation Handbook; Elsevier: New York, NY, USA, 1983.

35. Wick, A.F.; Stahl, P.D.; Ingram, L.J.; Vicklund, L. Soil aggregation and organic carbon in short-term stockpiles. Soil Use Manag. 2009, 25, 311-319. [CrossRef]

(C) 2018 by the Natural Resources Canada. Licensee MDPI, Basel, Switzerland. This article is an open access article distributed under the terms and conditions of the Creative Commons Attribution (CC BY) license (http:/ / creativecommons.org/licenses/by/4.0/). 